\title{
Assessing the Microbial Safety Status of Spices and Condiments Sold in Faisalabad City of Pakistan
}

\section{Mujahid Hassan Khan*, Muhammad Afzaal, Ayesha Kiran and Muhammad Usman}

Institute of Home and Food Sciences, GCUF, Pakistan

*Corresponding Author: Mujahid Hassan Khan, Institute of Home and Food Sciences, GCUF, Pakistan.
Received: February 05, 2020

Published: April 06, 2020

(c) All rights are reserved by Mujahid Hassan., et al.

\section{Abstract}

Spices and condiments are mostly used in dehydrated form which deliver environs that permits the survival of various foodborne pathogens. Total 150 samples (Packed and Unpacked) of 11 different spices and condiments were originating from five different areas of Faisalabad and were screened for the microbial quality attributes, based on plate count and specified identification techniques. They were studied for incidence of Bacillus cereus, C. perfringens, Salmonella spp. and yeast mold counts. It was concluded that 9 samples (6.00\%) from total 150 were positive with Salmonella incidence. Black Pepper was with maximum reading (18.8\%). This study reveals that incidence of $B$. cereus was (18.00\%) out of total samples with maximum incidence samples of ginger powder (33.3\%). As we are concerned by C. perfringens the total incidence was (10.66\%) with maximum observation in Black pepper (27.2\%). Maximum incidence of yeast and mold was observed in parsley chopped $5.24 \log _{10} \mathrm{cfu} \mathrm{g}^{-1}$ with all the samples positive with yeast and mold, turmeric and salt samples had yeast mold counts in tolerable limits. This study was conducted to determine the microbiological safety level of spices and condiments sold in the markets of Faisalabad city of Pakistan by dividing the city into five regions.

Keywords: Becillus Cereus; Spices; Microbiology; Salmonella

\section{Introduction}

The higher levels of microbial infection in spices and Condiments are reported by various studies reviewed proposes a need for enhanced control in all aspects of the production processing and usage of these products to avoid potential food spoilage and food-borne sicknesses due to contaminated spices and condiments. In developing countries food born pathogens are the major source of diseases and infections. Spices are defined by the US Food and Drug Administration (FDA) as "any aromatic vegetable substance in the whole, broken or ground form, except for those substances which have been traditionally regarded as foods, such as onions, garlic and celery; whose significant function in food is seasoning rather than nutritional; that is true to name; and from which no portion of any volatile oil or other flavouring principle has been removed" (FDA 2009). Spices and Condiments have been utilised for multiple functions for many centuries. In early times, spices and condiments were so worth able that they were used as a form of money and, for several years, they were so costly that they were available to the very rich only. Spices were not only used for seasoning foods, but also were often used as fragrances, cosmetics and aphrodisiacs [1,2]. Ancient Greeks, Romans and Chinese writings indicated that spices and condiments were frequently used for therapeutic purposes. The use of spices and condiments for medicinal and cosmetic purposes still seen today [1]. Food spices and condiments have strong smell, sharp taste substances usually used to enhance or alter the flavour of food. They are generally of vegetable derivation $[3,4]$. Commonly include Black pepper, Red pepper, powdered, hot, Red pepper, powdered, sweet, Cumin powder, Ginger, powdered, Coriander, powdered, Curry powder, Parsley, chopped, dill chopped, Mint, chopped and turmeric powder. Spices and condiments contribute more than aesthetic properties to foods. Outbreaks due to spices and condiments is specified by a number of confirmed cases. As many patients don't seek care or they don't have performed stool culture so these numbers represent only a small portion of the total illness. Secondly, spices and condiments are used in a minute quantity as ingredients in the dishes so it's difficult to implicate. Nevertheless, the discussed examples show that spices and condiments infected with Salmonella of various serotypes might be liable for foodborne outbreaks. In the US, two Salmonella outbreaks related to spices occurred in 2009 and 2010 [5]. In the year 2010272 cases were reported in United States (44 states, DC) due to red and black pepper $[5,6]$. Faisalabad is a big city with more than 3.204 million populations. According to the IQAir (Institute for air quality determination) visuals report 2018 Faisalabad is listed as the third most air polluted city in the world. Many spices and condiments are grown-up and harvested in poor hygienic conditions in areas abundant in humidity and warmth. So, these conditions lay the foundation for potential microbial contaminations. Several studies have specified higher microbial loads in spices and condiments which could pose a problem for food producers and consumers [1]. Moreover, to avoid this heavy bacterial contamination and succeeding possible degrada- 
tion of foods applied with, bacterial counts as low as possible are crucial. Generally, the microbiological value of spices and condiments often mirrors the hygienic conditions of their production and manufacture region. It's evident like in many other agricultural harvests, spices and condiments are exposed to microbiological contamination at countless stages. As pathogens like B. cereus, $C$. perfringens, Salmonella spp. and toxic molds could be found with these products, procedures have been applied to sterilize the products or - at least - to reduce the microbiological load significantly $[4,7,8]$. Sanitation and flavour characters are considered as the most important two factors while evaluating quality of spices and condiments. According to the hygiene standards, Spices and condiments should neither contain pathogenic microbes, nor insects rather must be reasonably free from extraneous stuff and flawed material [4]. The popularity of highly spiced cuisine and consumer demand for more flavourful foodstuffs have resulted in an enduring interest in the use of spices and condiments in food products. Studies exploring bacterial and fungal contamination of spices, herbs and condiments are reread.

\begin{tabular}{|l|c|c|}
\hline Spices/condiments & \multicolumn{1}{|c|}{ Origin $^{\mathbf{a}}$} & Packaging Materials $^{\mathbf{b}}$ \\
\hline Black pepper & Indonesia, Malaysia & PEA, P, O \\
\hline Coriander powdered & Bulgaria, Hungary & PEA, G, O \\
\hline Cumin powder & Iran & PE, O \\
\hline Curry powder & India, Sri Lanka & G, P, PEA, O \\
\hline Dill chopped & Germany & P, PEA, O \\
\hline Ginger powdered & U & G, PE, O \\
\hline Mint chopped & U & PE, O \\
\hline Parsley chopped & U & PE, O \\
\hline Red pepper hot & Hungary, Yugoslavia & PE, PEA, O \\
\hline Salt & $\begin{array}{c}\text { Greece and Ancient } \\
\text { Rome }\end{array}$ & PE, O \\
\hline Turmeric powder & India & PE, PEA, O \\
\hline
\end{tabular}

Table 1: Samples description.

Note* a U: Origin Unknown; ${ }^{\text {b}}$ G: Glass; P: Paper; PE: Polyethylene Bag; PEA: Aluminium-Coated Polyethylene Bag; O: Open [4].

\section{Aim of the Study}

This study aims to discover the microbial safety and hazards in the spices and condiments in Faisalabad, the city of Pakistan. So, for this purpose experiments were conducted and microbiological safety was analysed for the health benefits of people of Faisalabad, Pakistan.

\section{Revisions}

Spices and condiments are originally source of taste, aroma and antioxidant activity for manufactured food. Reports show that the spices essential oils have inhibitory affect towards poisonous microbes (Intro 1).
Spices and condiments are well known for stabilizing the food from microbiological deterioration and specifically some spices are evident to have inhibitory effect on food-spoilage microbes. Many spices are applied to treat infectious diseases [9].

Many investigations revealed that spices and condiments are well known for their medicinal, preservation and antioxidant properties [9-11].

\section{Materials and Methods \\ Sampling plan}

A total of 150 samples of 11 different spices and condiments were collected from 5 different localities of the city Faisalabad. A detailed description of samples is provided in the table 1. All the samples were stored at ambient temperature until examined. Open samples without packaging were placed in sterilised bags and were rinsed with $80 \%$ alcohol and bags were cut using sterilised scissors in order prevent any possibility of letting microbes invade into the samples before applying tests. The samples evaluated in triplicate in case of plate counts and duplicate in case of detection of pathogenic microorganisms.

Samples of Black pepper, Red pepper, powdered, hot, Cumin powder, Ginger powdered, Coriander, powdered, Curry powder, Parsley chopped, dill chopped, Mint, turmeric powder and salt and turmeric powder were collected and transported to the working laboratory with care.

Samples were collected from retailers were kept in sterilised plastic bags and were properly labelled and aseptically transferred to the laboratory in case of non-packaged spices and condiments.

\begin{tabular}{|l|c|c|c|c|c|c|}
\hline $\begin{array}{l}\text { Spice/ } \\
\text { Condiment }\end{array}$ & $\begin{array}{c}\text { D- } \\
\text { Ground }\end{array}$ & $\begin{array}{c}\text { Jhang } \\
\text { Road }\end{array}$ & $\begin{array}{c}\text { Canal } \\
\text { Road }\end{array}$ & $\begin{array}{c}\text { Kotwali } \\
\text { Road }\end{array}$ & $\begin{array}{c}\text { Sargodha } \\
\text { Road }\end{array}$ & $\begin{array}{c}\text { Total } \\
\text { No. } \\
\text { Sample }\end{array}$ \\
\hline Black Pepper & 3 & 2 & 1 & 2 & 3 & 11 \\
\hline $\begin{array}{l}\text { Red } \\
\text { Pepper Hot }\end{array}$ & 4 & 2 & 3 & 3 & 3 & 15 \\
\hline $\begin{array}{l}\text { Cumin } \\
\text { powder }\end{array}$ & 1 & 3 & 2 & 1 & 2 & 09 \\
\hline $\begin{array}{l}\text { Ginger } \\
\text { Powder }\end{array}$ & 2 & 4 & 2 & 3 & 1 & 12 \\
\hline $\begin{array}{l}\text { Coriander } \\
\text { powdered }\end{array}$ & 4 & 2 & 3 & 5 & 3 & 17 \\
\hline $\begin{array}{l}\text { Curry } \\
\text { powder }\end{array}$ & 1 & 4 & 5 & 1 & 5 & 16 \\
\hline $\begin{array}{l}\text { Parsley } \\
\text { chopped }\end{array}$ & 5 & 3 & 4 & 2 & 4 & 18 \\
\hline \begin{tabular}{l} 
Dill chopped \\
\hline $\begin{array}{l}\text { Mint } \\
\text { chopped }\end{array}$
\end{tabular} & 2 & 2 & 1 & 2 & 1 & 09 \\
\hline $\begin{array}{l}\text { Turmeric } \\
\text { powder }\end{array}$ & 4 & 1 & 2 & 4 & 3 & 14 \\
\hline Salt & 1 & 3 & 4 & 2 & 3 & 13 \\
\hline Total & 30 & 30 & 30 & 30 & 30 & 150 \\
\hline
\end{tabular}

Table 2: Sample collection plan. 
Methodology

Analysis for the pathogens in spices and condiments has proven problematic for many reasons (e.g. antimicrobials). Therefore, many approaches have been considered to determine best analysis scheme for the spices and condiments, whether it's an examination for pathogen directly or enrichment to enhance the detection [12].

\begin{tabular}{|l|c|c|}
\hline \multicolumn{1}{|c|}{ Origin } & Antimicrobial agent & Examples \\
\hline $\begin{array}{l}\text { Plants, pre- } \\
\text { infectional }\end{array}$ & $\begin{array}{c}\text { Organic acids Phenolic com- } \\
\text { pounds }\end{array}$ & $\begin{array}{c}\text { Herbs, spices } \\
\text { and other plants }\end{array}$ \\
\cline { 2 - 3 } & Methylated flavones Flavonols & NA \\
\cline { 2 - 3 } & $\begin{array}{c}\text { Alkaloids (e.g., } \alpha \text {-tomatine) } \\
\text { Hydroxyphenyl-threne deriva- } \\
\text { tives }\end{array}$ & Lactones \\
\cline { 2 - 3 } & $\begin{array}{c}\text { Protein-like compounds Gluco- } \\
\text { sides, glycosides, dienes }\end{array}$ & NA \\
\hline $\begin{array}{l}\text { Plants, } \\
\text { post } \\
\text { infectional }\end{array}$ & \begin{tabular}{c} 
Phenolic compounds Sulfoxides \\
\cline { 2 - 3 }
\end{tabular} & $\begin{array}{c}\text { Infected or } \\
\text { Injured plants }\end{array}$ \\
\hline
\end{tabular}

Table 3: Major natural antimicrobial systems ${ }^{a}$.

Note* a Adapted from [12-14].

Abbreviation: NA: Not Available.

Determination of microbiological characteristics

The microbial examination of spices and condiments samples included determination of Salmonella spp., B. cereus, C. perfringens and yeast mold count.

\section{Salmonella spp. prevalence}

In case of open samples sealed in plastic bags the sample bags were disinfected using $80 \%$ ethanol, then by using sterilized scissors bag were. A portion (25g) of samples was transmitted to stomacher bag or beaker using sterilized spoon [15]. After 1-hour incubation at room temperature, $\mathrm{pH}$ was adjusted to 6.8. Then samples were incubated at $35^{\circ} \mathrm{C}$ for 24 hours and portions $(1.0$ and $0.1 \mathrm{ml}$ ) of each culture were added to $10 \mathrm{ml}$ of tetrathionate (TT) broth (Oxoid, Basingstoke, Hampshire, UK) and Rappaport-Vassiliadis (RV) broth (Oxoid), respectively. After incubation at $42^{\circ} \mathrm{C}$ for 24 hours, the cultures were streaked onto two plates each of XLD agar (Oxoid) and CHRO Magar Salmonella (CHRO Magar, Paris, France), directly or after immunomagnetic separation (IMS) with Dynabeads anti-Salmonella (Dynal, Oslo, Norway), according to the manufacturer's instructions. After incubation at $35^{\circ} \mathrm{C}$ for $24 \mathrm{~h}$, a portion of the suspected colonies was tested for agglutination with a Salmonella antibody kit (Unipath, Oxoid) and confirmed using the biochemical characteristics on triple sugar iron agar (Eiken Chemical, Tokyo, Japan) and lysine indole motility agar (Eiken Chemical). Confirmed isolates were further serotyped for agglutination against Salmonella $\mathrm{O}$ and $\mathrm{H}$ antigens (Denkaseiken, Tokyo, Japan).

\section{B. cereus prevalence}

Samples were stored at room temperatures until analysed. Dilutions of one sample unit $(10 \mathrm{~g})$ from each of the field samples were prepared in accordance with standard method M-1.0 of the American Spice Trade Association [16], and the pour plates made in Standard Plate Count Agar (Difco). The method doesn't include mechanical blending of spices, because that could release the antibacterial agents. The petri plates were then incubated at $30^{\circ} \mathrm{C}$ for $24-48 h$.

\section{C. perfringens prevalence}

For the plate count determination, one gram portions of sample were weighed in screw capped 18 X 150-mm tubes having $9 \mathrm{ml}$ sterile $(0.85 \% \mathrm{wt}$./vole) saline mixed gently and then stored for 30 minutes at room temperature $\left(25-30^{\circ} \mathrm{C}\right)$ to permit separation of microbes from the sample material, then samples were vigorously vortexed for a minute. The mixture was left for about 5 minutes to allow coarse particles to settle $[4,17]$.

\section{Isolation of $C$. perfringens}

Proper decimal dilutions of supernatant liquid were made using saline and plated by using Shahidi Ferguson Perfringens (SFP) base agar (Difco, Detroit, MI) supplemented with 0.5\% neomycin and $0.2 \%$ polymyxin B. Plates were incubated anaerobically at $37^{\circ} \mathrm{C}$ for $24 \mathrm{~h}$ in a mixture of $5 \% \mathrm{CO}_{2}$ and $95 \%$ N2 Precipitate zone surrounded black colonies were enumerated and five were inoculated into cooked meat medium (Difco) and held as stock cultures at room temperature. Two drops of stock cultures of each presumptive isolate of $C$. perfringens were added to $10 \mathrm{ml}$ of fluid thioglycolate medium (Difco) and incubated for 16 - 18 hours at $37^{\circ} \mathrm{C}$. Activated cultures were inoculated into confirmatory media (motility-nitrate medium and lactose-gelatin medium) and incubated anaerobically for $24 \mathrm{~h}$ at $37^{\circ} \mathrm{C}$ as previously described $[17,18]$. No motile cultures showing typical microscopic morphology that were positive on lactose, nitrate reduction, and gelatin were considered to be $C$. perfringens.

Yeast and mold count

Dilutions which were prepared for total plate count used making spread plates over Potato Dextrose Agar PDA (Difco). The plates were then incubated at $23^{\circ} \mathrm{C}$ for 96 hours before counting colonies of yeast and mould. Sterile, screw-cap tube having $10 \mathrm{ml}$ of initial blend was immersed in water bath at $70^{\circ} \mathrm{C}$ for 10 minutes, then was removed and rapidly cooled in ice bath. Decimal dilutions were further prepared and plated. Plates were poured and capped with PCA followed by incubation for 48 hours at $30^{\circ} \mathrm{C}$ for Spore count [19]. 
Results and Discussions

\begin{tabular}{|c|c|c|c|c|c|c|c|c|c|c|c|c|}
\hline \multirow[b]{2}{*}{ Spices } & \multicolumn{2}{|c|}{ D-Ground } & \multicolumn{2}{|c|}{ Jhang Road } & \multicolumn{2}{|c|}{ Canal Road } & \multicolumn{2}{|c|}{ Kotwali Road } & \multicolumn{2}{|c|}{ Sargodha Road } & \multirow{2}{*}{$\begin{array}{l}\text { Total +ve } \\
\text { samples }\end{array}$} & \multirow[b]{2}{*}{$\%$ age } \\
\hline & \begin{tabular}{|c} 
Total \\
Samples
\end{tabular} & $+v e$ & $\begin{array}{c}\text { Total } \\
\text { Samples }\end{array}$ & $+v e$ & $\begin{array}{c}\text { Total } \\
\text { Samples }\end{array}$ & $+v e$ & \begin{tabular}{c|} 
Total \\
Samples
\end{tabular} & $+v e$ & $\begin{array}{c}\text { Total } \\
\text { Samples }\end{array}$ & +ve & & \\
\hline Black Pepper & 3 & - & 2 & - & 1 & 1 & 2 & 1 & 3 & - & $2 / 11$ & $18.8 \%$ \\
\hline Red Pepper & 4 & 1 & 2 & - & 3 & 1 & 3 & - & 3 & - & $2 / 15$ & $13.3 \%$ \\
\hline Cumin powder & 1 & - & 3 & - & 2 & - & 1 & - & 2 & - & $0 / 9$ & Nil \\
\hline Ginger Powder & 2 & - & 4 & - & 2 & - & 3 & - & 1 & - & $0 / 12$ & Nil \\
\hline Coriander & 4 & - & 2 & - & 3 & - & 5 & - & 3 & - & $0 / 17$ & Nil \\
\hline Curry powder & 1 & - & 4 & 1 & 5 & 2 & 1 & - & 5 & - & $3 / 16$ & $18.7 \%$ \\
\hline \begin{tabular}{|l|}
$\begin{array}{l}\text { Parsley } \\
\text { chopped }\end{array}$ \\
\end{tabular} & 5 & - & 3 & - & 4 & - & 2 & - & 4 & 1 & $1 / 18$ & $5.5 \%$ \\
\hline Dill chopped & 3 & - & 2 & 1 & 1 & - & 2 & - & 1 & - & $1 / 9$ & $11.1 \%$ \\
\hline Mint chopped & 2 & - & 4 & - & 3 & - & 5 & - & 2 & - & $0 / 16$ & Nil \\
\hline $\begin{array}{l}\text { Turmeric } \\
\text { Powder }\end{array}$ & 4 & - & 1 & - & 2 & - & 4 & - & 3 & - & $0 / 14$ & Nil \\
\hline Salt & 1 & - & 3 & - & 4 & - & 2 & - & 3 & - & $0 / 13$ & Nil \\
\hline Total & 30 & $1(3.3 \%)$ & 30 & $2(6.6 \%)$ & 30 & $4(13.3 \%)$ & 30 & $1(3.3 \%)$ & 30 & $1(3.3 \%)$ & $9 / 150$ & $6.0 \%$ \\
\hline
\end{tabular}

Table 4: Prevalence of Salmonella in samples.

The table shows the results of testing the Salmonella incidence in the samples of spices and condiments. It was observed that Salmonella was present in Black pepper (18.8\%), Red pepper (13.3\%), Curry powder (18.7\%), Parsley (5.5\%) and Dill (11.1\%). Highest level was noted in Black pepper (18.8\%). The study reveals the unsatisfactory microbiological status of safety. Although cumin, ginger, coriander, mint chopped, turmeric and salt were satisfactory with Salmonella incidence. The major reason was the unpackaged spices sold in the market. C anal road samples were higher in Salmonella count (13.3\%) as compared to the other regions of the city.
As described in the table B. cereus was found to be intolerable as its prevalence was observed in samples with maximum count in Ginger powder (33.3\%). Further in other spices and condiments the contamination levels were as follows Black pepper (26.6\%), Cumin powdered (22.2\%), Curry powder (21.2\%), Parsley (27.7\%), Dill (22.2\%), Turmeric (28.5\%) and Salt (15.3\%). Black pepper, Coriander and Mint chopped were negative with Salmonella and were acceptable. Kotwali road was the locality where the prevalence of the B. cereus was maximum as compared to others areas of the city.

\begin{tabular}{|c|c|c|c|c|c|c|c|c|c|c|c|c|}
\hline \multirow[b]{2}{*}{ Spices } & \multicolumn{2}{|c|}{ D-Ground } & \multicolumn{2}{|c|}{ Jhang Road } & \multicolumn{2}{|c|}{ Canal Road } & \multicolumn{2}{|c|}{ Kotwali Road } & \multicolumn{2}{|c|}{ Sargodha Road } & \multirow{2}{*}{$\begin{array}{l}\text { Total +ve } \\
\text { samples }\end{array}$} & \multirow[b]{2}{*}{$\%$ age } \\
\hline & $\begin{array}{c}\text { Total } \\
\text { Samples }\end{array}$ & +ve & $\begin{array}{c}\text { Total } \\
\text { Samples }\end{array}$ & $+v e$ & $\begin{array}{c}\text { Total } \\
\text { Samples }\end{array}$ & +ve & $\begin{array}{c}\text { Total } \\
\text { Samples }\end{array}$ & +ve & $\begin{array}{c}\text { Total } \\
\text { Samples }\end{array}$ & $+v e$ & & \\
\hline Black Pepper & 3 & - & 2 & - & 1 & - & 2 & - & 3 & - & $0 / 11$ & Nil \\
\hline Red Pepper & 4 & 1 & 2 & - & 3 & 1 & 3 & 2 & 3 & - & $4 / 15$ & $26.6 \%$ \\
\hline Cumin powder & 1 & - & 3 & 1 & 2 & - & 1 & - & 2 & 1 & $2 / 9$ & $22.2 \%$ \\
\hline Ginger Powder & 2 & - & 4 & 2 & 2 & 1 & 3 & 1 & 1 & - & $4 / 12$ & $33.3 \%$ \\
\hline Coriander & 4 & - & 2 & - & 3 & - & 5 & - & 3 & - & $0 / 17$ & Nil \\
\hline Curry powder & 1 & 1 & 4 & - & 5 & 1 & 1 & - & 5 & 3 & $5 / 16$ & $31.2 \%$ \\
\hline $\begin{array}{l}\text { Parsley } \\
\text { chopped }\end{array}$ & 5 & 2 & 3 & - & 4 & - & 2 & 1 & 4 & 2 & $5 / 18$ & $27.7 \%$ \\
\hline Dill chopped & 3 & - & 2 & 2 & 1 & - & 2 & - & 1 & - & $2 / 9$ & $22.2 \%$ \\
\hline Mint chopped & 2 & - & 4 & - & 3 & - & 5 & - & 2 & - & $0 / 16$ & Nil \\
\hline \begin{tabular}{|l} 
Turmeric \\
Powder
\end{tabular} & 4 & 1 & 1 & - & 2 & - & 4 & 2 & 3 & - & $4 / 14$ & $28.5 \%$ \\
\hline Salt & 1 & - & 3 & 1 & 4 & - & 2 & 1 & 3 & - & $2 / 13$ & $15.3 \%$ \\
\hline Total & 30 & $5(16.6 \%)$ & 30 & $6(20 \%)$ & 30 & $3(10.0 \%)$ & 30 & $7(23.3 \%)$ & 30 & $6(20 \%)$ & $27 / 150$ & $18.0 \%$ \\
\hline
\end{tabular}

Table 5: Prevalence of B. cereus in samples. 


\begin{tabular}{|c|c|c|c|c|c|c|c|c|c|c|c|c|}
\hline \multirow[b]{2}{*}{ Spices } & \multicolumn{2}{|c|}{ D-Ground } & \multicolumn{2}{|c|}{ Jhang Road } & \multicolumn{2}{|c|}{ Canal Road } & \multicolumn{2}{|c|}{ Kotwali Road } & \multicolumn{2}{|c|}{ Sargodha Road } & \multirow{2}{*}{$\begin{array}{l}\text { Total +ve } \\
\text { samples }\end{array}$} & \multirow[b]{2}{*}{$\%$ age } \\
\hline & $\begin{array}{c}\text { Total } \\
\text { Samples }\end{array}$ & $+v e$ & $\begin{array}{c}\text { Total } \\
\text { Samples }\end{array}$ & $+v e$ & $\begin{array}{c}\text { Total } \\
\text { Samples }\end{array}$ & $+v e$ & $\begin{array}{c}\text { Total } \\
\text { Samples }\end{array}$ & +ve & $\begin{array}{c}\text { Total } \\
\text { Samples }\end{array}$ & $+v e$ & & \\
\hline Black Pepper & 3 & 1 & 2 & - & 1 & 1 & 2 & 1 & 3 & - & $3 / 11$ & $27.2 \%$ \\
\hline Red Pepper & 4 & 2 & 2 & - & 3 & - & 3 & - & 3 & 1 & $3 / 15$ & $20 \%$ \\
\hline Cumin powder & 1 & - & 3 & - & 2 & - & 1 & - & 2 & - & $0 / 9$ & Nil \\
\hline Ginger Powder & 2 & 1 & 4 & 1 & 2 & - & 3 & - & 1 & - & $2 / 12$ & $16.6 \%$ \\
\hline Coriander & 4 & 1 & 2 & - & 3 & 1 & 5 & 2 & 3 & - & $4 / 17$ & $23.5 \%$ \\
\hline Curry powder & 1 & - & 4 & - & 5 & - & 1 & - & 5 & 2 & $2 / 16$ & $12.5 \%$ \\
\hline $\begin{array}{l}\text { Parsley } \\
\text { chopped }\end{array}$ & 5 & - & 3 & - & 4 & - & 2 & - & 4 & - & $0 / 18$ & Nil \\
\hline Dill chopped & 3 & 2 & 2 & - & 1 & - & 2 & - & 1 & - & $2 / 9$ & $22.2 \%$ \\
\hline Mint chopped & 2 & - & 4 & - & 3 & - & 5 & - & 2 & - & $0 / 16$ & Nil \\
\hline \begin{tabular}{|l} 
Turmeric \\
Powder
\end{tabular} & 4 & - & 1 & - & 2 & - & 4 & - & 3 & - & $0 / 14$ & Nil \\
\hline Salt & 1 & - & 3 & - & 4 & - & 2 & - & 3 & - & $0 / 13$ & Nil \\
\hline Total & 30 & $7(3.3 \%)$ & 30 & $1(10 \%)$ & 30 & $2(6.6 \%)$ & 30 & $3(3.3 \%)$ & 30 & $3(3.3 \%)$ & $16 / 150$ & $10.66 \%$ \\
\hline
\end{tabular}

Table 6: Prevalence of C. perfringens in samples.

The study reveals that ginger, coriander, parsley, dill and turmeric were safer microbiologically with no incidence of Salmonella. Moreover, black pepper (7.14\%), Red pepper (6.6\%), Cumin Powder (28.5\%), Curry powder (20\%), mint (13.3\%) and salt (14.2\%). Overall 7.83\% samples were positive with C. perfringens out of 166 samples. Maximum incidence was found in cumin powder (28.5\%). Maximum positive samples were from Kotwali road.
We revealed by conducting tests the overall yeast mold counts present in the spices and condiments that maximum incidence of yeast and mold was observed in parsley chopped which was 5.24 $\log _{10} \mathrm{cfu} \mathrm{g}^{-1}$ with all the samples positive with yeast and mold count. Turmeric powder and salt were the samples with tolerable limits of yeast and mold count having $0 \%$ incidence.

\begin{tabular}{|l|c|c|c|}
\hline \multicolumn{1}{|c|}{ Samples } & No. of samples tested & YM Count Range ${\mathbf{~} \log _{\mathbf{1 0}} \mathbf{c f u} \mathbf{g}^{-\mathbf{1}} \text { ) }}^{\text {Frequency* }}$ \\
\hline Black Pepper & 11 & $<2.00-4.00$ & $72 \%$ \\
\hline Red Pepper & 15 & $<2.00-3.21$ & $53 \%$ \\
\hline Cumin powder & 09 & $<2.00-4.45$ & $20 \%$ \\
\hline Ginger Powder & 12 & $<2.00-3.84$ & $52 \%$ \\
\hline Coriander & 17 & $<2.00-3.50$ & $8 \%$ \\
\hline Curry powder & 16 & $<2.00-2.00$ & $100 \%$ \\
\hline Parsley chopped & 18 & $<2.00-5.24$ & $20 \%$ \\
\hline Dill chopped & 09 & $<2.00-2.60$ & $27 \%$ \\
\hline Mint chopped & 16 & $<2.00-3.27$ & 0 \\
\hline Turmeric Powder & 14 & $<2.00$ & 0 \\
\hline Salt & 13 & $<2.00$ & \\
\hline
\end{tabular}

Table 7: Prevalence of Yeast mould in samples.

Note: *: Frequency is the percentage of contaminated samples.

Abbreviations: YM: Yeast and Mold; CFU: Colony Forming Units.

\section{Conclusion}

This study was made to reveal the microbial contamination of Spices and Condiments being sold in the major markets and retailer shops of Faisalabad the city of Pakistan. The prevalence of Cereus was higher as compared to others like Salmonella, C. per- fringens. Packaged Spices and Condiments were relatively safer as compared to the openly sold by the retailers. Poor sanitary conditions of the keeping place and personal hygiene of workers handling these Spices and Condiments. 


\section{Bibliography}

1. McKee LH. "Microbial Contamination of Spices and Herbs: A Review". LWT-Food Science and Technology 28.1 (1995): 1-11.

2. Parry John W. "The Story of Spices". Chemical Publ. Co. Inc., New York, USA (1953).

3. Odebunmi EO., et al. "Comparative Proximate Analysis of Some Food Condiments". Journal of Applied Sciences Research 6.3 (2010): 272-274.

4. Kneifel Wolfgang and Erika Berger. "Microbiological Criteria of Random Samples of Spices and Herbs Retailed on the Austrian Market". Journal of Food Protection 57.10 (1994): 893901.

5. Gieraltowski L., et al. "Nationwide Outbreak of Salmonella montevideo Infections Associated with Contaminated Imported Black and Red Pepper: Warehouse Membership Cards Provide Critical Clues to Identify the Source". Epidemiology and Infection 141.6 (2013): 1244-1252.

6. Zweifel Claudio and Roger Stephan. "Spices and Herbs as Source of Salmonella-Related Foodborne Diseases". Food Research International 45.2 (2012): 765-769.

7. Sharma Arun., et al. "Microbiological Status and Antifungal Properties of Irradiated Spices". Journal of Agricultural and Food Chemistry 32.5 (1984): 1061-1063.

8. SHARMA., et al. "Assessment of Microbiological Quality of Some Gamma Irradiated Indian Spices". Journal of Food Science 54.2 (1989): 489-490.

9. Chakraborty M., et al. "Microbiological Quality and Antimicrobial Potential of Extracts of Different Spices". Food Research 4.2 (2020): 375-379.

10. Joe M., et al. "Antimicrobial Activity of Some Common Spices against Certain Human Pathogens". Journal of Medicinal Plants Research 3.11 (2009): 1134-1136.

11. Das S., et al. "Synergistic or Additive Antimicrobial Activities of Indian Spice and Herbal Extracts against Pathogenic, Probiotic and Food-Spoiler Micro-Organisms" (2012).

12. Gurtler Joshua B and Susanne E Keller. "Microbiological Safety of Dried Spices". Annual Review of Food Science and Technology 10 (2019): 409-427.

13. Hsieh RJ and JE Kinsella. "Oxidation of Polyunsaturated Fatty Acids: Mechanisms, Products, and Inhibition with Emphasis on Fish". Advances in Food and Nutrition Research 33 (1989): 233-341.
14. Beuchat Larry R and David A Golden. "Antimicrobials Occurring Naturally in Foods". Food Technology (USA) (1989).

15. Johnston Lynette M., et al. "A Field Study of the Microbiological Quality of Fresh Produce". Journal of food protection 68.9 (2005): 1840-1847.

16. Seenappa M and AG Kempton. "A Note on the Occurrence of Bacillus Cereus and Other Species of Bacillus in Indian Spices of Export Quality". Journal of Applied Bacteriology 50.2 (1981): 225-228.

17. Rodriguez-Romo Luis A., et al. "Detection of Enterotoxigenic Clostridium Perfringens in Spices Used in Mexico by Dot Blotting Using a DNA Probe". Journal of Food Protection 61.2 (1998): 201-204.

18. Kramer JM., et al. "Foodborne Bacterial Pathogens". By MP Doyle, Marcel Dekker, Inc., New York and Basel (1989): 22-70.

19. Julseth RM and RH Deibel. "Microbial Profile of Selected Spices and Herbs at Import". Journal of Milk and Food Technology 37.8 (1974): 414-419.

\section{Assets from publication with us}

- Prompt Acknowledgement after receiving the article

- Thorough Double blinded peer review

- Rapid Publication

- Issue of Publication Certificate

- High visibility of your Published work

Website: https://www.actascientific.com/

Submit Article: https://www.actascientific.com/submission.php Email us: editor@actascientific.com

Contact uS: +919182824667 